archives-ouvertes

\title{
Editorial: Matrix Proteins
}

\author{
Stéphane Germain, Ariel Di Nardo
}

\section{To cite this version:}

Stéphane Germain, Ariel Di Nardo. Editorial: Matrix Proteins. 2019, 10.1016/j.semcdb.2019.03.001 . hal-02380150

\section{HAL Id: hal-02380150 \\ https://hal.archives-ouvertes.fr/hal-02380150}

Submitted on 26 Nov 2019

HAL is a multi-disciplinary open access archive for the deposit and dissemination of scientific research documents, whether they are published or not. The documents may come from teaching and research institutions in France or abroad, or from public or private research centers.
L'archive ouverte pluridisciplinaire HAL, est destinée au dépôt et à la diffusion de documents scientifiques de niveau recherche, publiés ou non, émanant des établissements d'enseignement et de recherche français ou étrangers, des laboratoires publics ou privés. 


\section{Editorial: Matrix Proteins}

Extracellular matrix (ECM) proteins contribute to both basement membrane and interstitial matrix which are dynamic structures that together regulate a variety of cellular and morphogenetic events. The ECM acts as a structural scaffold that establishes tissue architecture and integrates transmission of mechanical and biochemical cues. In this special issue on 'matrix proteins', biological activities are reviewed by experts in the field.

Collagens are the most abundant vertebrate ECM proteins. They form a superfamily of 28 members that show a remarkable diversity in molecular and supramolecular organization, tissue distribution and function. Mutations in collagen genes result in a wide range of inherited connective tissue diseases. As reviewed by Bretaud and colleagues, unexpected and very diverse regulatory and mechanical functions of collagen have been reported. However, the structural and functional landscape of the collagen superfamily is still far from being complete, and Zebrafish has emerged over the last decades as a powerful model to interrogate gene function related to this family.

Fibrillin microfibrils, reviewed by Thomson and colleagues, are extensible polymers that endow connective tissues with long-range elasticity and have widespread distributions in both elastic and nonelastic tissues. They act as a template for elastin deposition during elastic fibre formation and are essential for maintaining the integrity of tissues such as blood vessels, lung, skin and ocular ligaments. Interestingly, mutations in fibrillin and fibrillin-binding proteins can also cause diseases linked to dysregulated growth factor signalling, pointing to a major functional role for fibrillin.

Matrix proteins in the central nervous system are involved in brain development, physiology and repair. Roll and Faissner review the structure and function of the tenascin proteins, which regulate diverse processes through interactions within the ECM. During development, these processes include cell differentiation, adhesion and migration, while in the adult brain, they include neurogenesis, synaptic plasticity and immune response upon injury. For example, tenascins are needed in the postnatal brain for the formation of perineuronal nets, which are highly condensed ECM structures.

Perineuronal nets, reviewed in detailed by Testa and colleagues, are a heterogeneous mix of complex sugars and proteins tightly linked to exert several physiological functions such as ion buffering and signal transduction in the brain. They influence neuronal activity and are greatly implicated in the closure of critical periods of heightened brain plasticity that impact learning and memory. Attesting to their vital importance, their disruption may lead to pathologies such as schizophrenia and addictions, and they are impacted by brain insults and neurodegenerative diseases. Accordingly, perineuronal net proteins, including tenascin, are gaining attention as therapeutic targets for altering brain physiology and countering brain dysfunction or injury.

The skin contains a highly developed ECM that is mechanically tough yet flexible. A large number of genetic and acquired ECM diseases with skin manifestations illustrate the importance of correct ECM assembly for dermal homeostasis. Here, Nyström and BrucknerTuderman present the composition and features of the skin ECM during homeostasis and regeneration. They also discuss ECM diseases affecting skin and ensuing therapeutic strategies.

The ECM of blood vessels, which is composed of both the vascular basement membrane and the interstitial ECM, is identified as a crucial component of the vasculature. Marchand and colleagues summarize how vascular ECM is organized and scaffolded to provide structural support for blood vessels. They also describe how it regulates endothelial cell and pericyte functions and how it is required for proper vascular morphogenesis and maintenance of vascular homeostasis.

The ECM is also a major component of the tumour microenvironment, which includes the ensemble of cellular and acellular components surrounding and interacting with tumour cells. As tumour progression and dissemination critically depend on support from its microenvironment, alterations in ECM abundance, integrity, and mechanical properties have been correlated with poorer prognosis for cancer patients. Naba and Socovich review the tumour proteome, or "matrisome", which has remained until recently largely unexplored. They present recent developments in computational and proteomic technologies that have allowed for comprehensive characterization of matrisomes of different tumour types along with their microenvironmental niches. They also highlight novel ECM proteins playing functional roles in cancer progression that have the potential to be exploited as therapeutic targets.

Together, these articles provide welcomed insight into the diverse molecules and functions attributed to the ECM throughout the organism and we would like to thank the authors for their timely contributions.

Stéphane Germain, Ariel A. Di Nardo Centre for Interdisciplinary Research in Biology (CIRB), Collège de France, CNRS UMR 7241, INSERM U1050, PSL University, Labex MemoLife, 75005 Paris, France 